\title{
Sustainable Water Resources Management to Combat Desertification in the Nurra Region, Northwestern Sardinia, Italy
}

\author{
Giorgio Ghiglieri ${ }^{1,3}$, Giulio Barbieri ${ }^{2}$, Antonio Vernier $^{2}$, Alberto Carletti ${ }^{3}$, Daniele Pittalis ${ }^{1,3}$ \\ ${ }^{I}$ Department of Territorial Engineering, Geopedology and Applied Geology Section, \\ Desertification Research Group (NRD), University of Sassari, Via De Nicola 9, 07100 Sassari, Italy \\ ${ }^{2}$ Department of Territorial Engineering, Applied Geology and Applied Geophysics Section, \\ University of Cagliari, Piazza D'Armi 1, 09100 Cagliari, Italy \\ ${ }^{3}$ Desertification Research Group (NRD), University of Sassari, Via De Nicola 9, 07100 Sassari, Italy
}

Received: 23 December 2009. Accepted: 15 June 2010.

\begin{abstract}
Sustainable water management plays an important role in the frame of the multidisciplinary research activities aiming to combat or to mitigate the desertification processes. The study activities have been carried out by RIADE Research Project (Integrated Research for Applying new technologies and processes for combating Desertification, www.riade.net). RIADE was co-financed by MIUR within the National Operative Programme 2000-2006. The primary objective was to explore and to develop models and strategies for innovative and sustainable solutions of water resources management, adopting a multidisciplinary approach, at the catchment and hydrogeological basin scale in a Mediterranean context, using a case history of a pilot area in NW Sardinia (Italy). The high concentration of population in this coastal zone and the intense agricultural activity have determined a relevant increase of water demand. This demand is generally satisfied by surface water, but, in some peculiar dry periods, it exceeds the available quantities. In these critical periods, groundwater are the only alternative source constituting a strategic water resource. The groundwater chemical properties are then correlated with the effects of the anthropogenic pressures. The used approach shows the application of groundwater protection criteria, in accordance with EU policies, and it was aimed to develop a methodological tool which can be applied to different scenarios.
\end{abstract}

Key-words: aquifer vulnerability, desertification, hydrogeology, Sardinia-Italy, water management.

\section{Introduction}

The Convention to Combat Drought and Desertification (UNCCD), adopted during the Conference of United Nation on Environment and Development held in Rio, defines Desertification as "land degradation in arid, semi-arid and dry sub-humid areas" deriving mainly from negative human impacts. The word "land" in this context comprises soil, water resources and natural vegetation (UNEP, 1994). This definition, which focuses mainly on soil degradation, may need an integration related to water resources. Moreover, the meaning given to the word "desertification", in common language, is generally linked to the concept of partial or total lack of water.

Both from a qualitative and a quantitative point of view, surface and groundwater resources are an essential factor for the conservation and development of any form of life. In fact, they represent an absolutely indispensable factor for the survival and the harmonic development of the natural environments and also for the socio-economical growth of the territory.

The deterioration of the water resources, which have negative impacts on the natural environments and on the socio-economic growth of an area, is a key indicator of desertification (UNEP, 1994; Barbieri et al., 2005; Ghiglieri et al., 2006, 2009b; http://www.riade.net). Such deterioration is actually one of the direct or concomitant causes of land degradation, rather than an effect of the desertification processes objectively noticeable, as in the case of damages occurring in the soils or woodlands.

* Corresponding Author: Tel.: +39 079 229269; Fax: +39 079 229261. E-mail address: ghiglieri@uniss.it. 
In the frame of the multidisciplinary research activities for combating and/or mitigating desertification, a proper water resources management plays an important role in the water conservation in terms of both quality and quantity (Barbieri et al., 2005; Ghiglieri et al., 2006, 2009a).

The present study has been carried out in the framework of the RIADE ${ }^{1}$ Project (Integrated Research for the Application of innovative technologies and procedures for combating Desertification) (http://www.riade.net).

One of the aims of the RIADE Project was to develop models and strategies for innovative approaches to sustainable water resources management, at the catchment and hydrogeological basin scale, applicable in the Mediterranean areas. Despite the considerable patrimony of experience and knowledge related to the desertification processes, only rarely the results of the studies have been turned into structured and integrated systems. This is largely due to focusing on local conditions or individual processes rather than on their complex interaction. In the effort for understanding a phenomenon that involves geology, soil science, climatology, hydrogeology, agronomy and forestry an interdisciplinary synergy is a key issue. A more holistic and systematic approach to the desertification processes, by means of an integrated project such as RIADE, has been developed.

The pilot area for the current study is one of the areas interested by the RIADE Project. This area is located in the Nurra plain (Alghero, NW Sardinia-Italy).

\section{Study area}

The Nurra district is located in the northwestern part of the island of Sardinia (Italy) in the Sassari Province. The study area covers an area of $586 \mathrm{~km}^{2}$. It is a part of the hydrogeological basin underlying the Calich coastal lagoon. The area is

\footnotetext{
1 The RIADE project is co-funded by MIUR (Italian Ministry for Education, University and Research) within the frame of the 2000-2006 National Operational Programme (PON) Research, Development and Higher Education. Partners ACS (Advanced Computer System), ENEA (Italian Agency for New Technologies, Energy and the Environment), University of Sassari (Desertification Research Group).
}

divided into two major sectors: the flatlands of the Alghero plain, in the northern part, and the rolling landscape that extends from Alghero to Villanova Monteleone, in the southern part.

Due to intensive human activities and recent climatic changes, the area has become vulnerable to the desertification processes. The water demand in the study area is considerable, water being required for industry, domestic use, tourism, agriculture, and animal rearing (Dono et al., 2008). Nurra relies on both surface and groundwater. The seasonal and perennial rivers of the area are exploited using the Cuga and Surigheddu dams, built on the highlands. However, like in other Mediterranean islands, surface water resources can periodically suffer of drastic shortage. Groundwater in different aquifers is exploited using deep boreholes which can attain discharges as high as $145 \mathrm{l} / \mathrm{s}$.

Notwithstanding the importance of local groundwater, as the main source of good quality water, and of their role of strategic reserve in such semiarid conditions, up to now their exploitation has been uncontrolled (Barbieri et al., 2005; Ghiglieri et al., 2006, 2009a). An additional problem in the Nurra district is that water users have a very scant knowledge of the provenance and the value of the fresh water they exploit, thus leading to a high rate of unofficial exploitation.

The extensive exploitation of the Nurra aquifers and the consequent water quality deterioration require a revision of current water management practices. This revision has to be based on a good knowledge of both the potential of aquifers in terms of geometry and the storage and the quality in terms of hydrogeochemical characteristics: up to now this knowledge has been disregarded.

The study area presents a complete stratigraphic sequence ranging in age from the Palaeozoic to Quaternary rock formations. An hydrogeological assessment has been developed using the data collected during the geological and structural surveys, the geophysical prospecting and a detailed hydrochemical study within the RIADE Project (Ghiglieri et al., 2006, 2009a). Five main hydrogeological units have been identified, divided in turn into 7 hydrogeologic complexes, characterized by medium-tohigh yield (Fig. 1). Groundwater in different aquifers is exploited using deep boreholes which can attain discharges as high as $145 \mathrm{l} / \mathrm{s}$ (Ghiglieri et al., 2009a). 


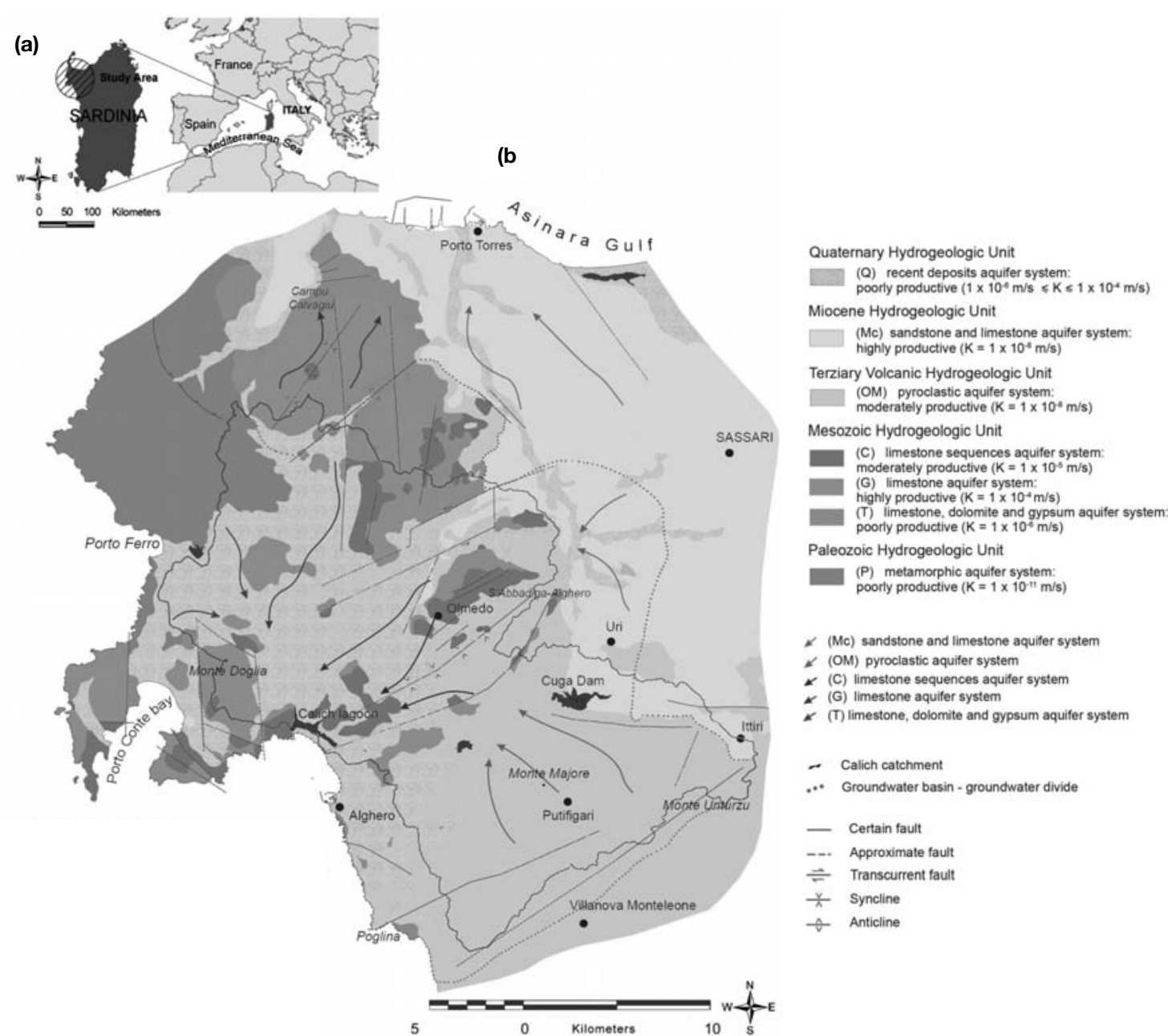

Figure 1. a) Study area; b) Hydrogeological map (modified from Ghiglieri et al., 2006, 2009a, 2009b).

\section{Materials and methods}

This work shows the application of groundwater protection criteria, in accordance with national and EU policies, within their integrated management.

An interdisciplinary methodological approach has been used to understand in particular all the geo-information and the human pressure. The study has required multi-source and multi-scales dataset including hydrogeological setting, soil map, land use map, groundwater monitoring data, actual or potential pollution sources, etc. This activity, which implied also surveys outside the study area, has been particularly time consuming (about 3 years) and difficult in terms of accessibility and logistics.

For each information a monographic data sheet has been edited; afterwards data were or- ganized in a digital database. The method used in this study for groundwater management incorporated a GIS mapping techniques.

\section{Results and discussion}

This report refers a synthesis of long lasted research, the main aims of which have been:

- to reconstruct the hydrogeological setting, the regional groundwater flow and the mean annual recharge for each aquifer (Ghiglieri et al., 2006, 2009a) (Tab. 1);

- to ascertain the origin of salinity in groundwater (Ghiglieri et al., 2006, 2009a);

- to recognise the boundary conditions of the different hydrogeologic units by mean of processes that control the concentration of the chemical major constituents in the dif- 
ferent aquifers (Ghiglieri et al., 2006, 2009a). The physico-chemical properties of groundwater sampled in the three monitoring sur- veys, don't show many difference in terms of the main parameters (Tab. 2). The investigated groundwater shows relatively high

Table 1. Mean annual recharge $\left(\mathrm{m}^{3}\right)$ estimated over 30 years (1961-1990), in 2003, 2004 and 2005 for the whole groundwater basin and for each aquifer.

\begin{tabular}{lrrrr}
\hline & $1961-1990$ & 2003 & 2004 & 2005 \\
\hline Groundwater Basin & $37.932 .413,92$ & $30.065 .157,17$ & $50.309 .425,02$ & $35.626 .865,46$ \\
\hline $\begin{array}{l}\text { Aquifer } \\
\text { cme(P) - metamorphic aquifer system }\end{array}$ & $228.739,86$ & $246.706,84$ & $458.094,29$ & $266.366,82$ \\
\hline $\begin{array}{l}\text { csc }(\mathrm{T}) \text { - limestone, dolomite and } \\
\text { gypsum aquifer system }\end{array}$ & $3.473 .303,32$ & $3.001 .686,45$ & $5.279 .983,34$ & $3.403 .945,29$ \\
\hline cc(G) - limestone aquifer system & $11.264 .766,24$ & $10.525 .715,24$ & $19.713 .341,58$ & $12.379 .228,44$ \\
\hline ccm $(\mathrm{C})$ - limestone sequences aquifer system & $3.650 .683,44$ & $3.200 .106,01$ & $5.572 .788,44$ & $3.884 .339,54$ \\
\hline cpi(OM) - pyroclastic aquifer system & $16.577 .742,40$ & $10.815 .989,50$ & $14.990 .298,22$ & $12.870 .855,76$ \\
\hline cmc(Mc) - sandstone and limestone aquifer system & $2.664 .432,15$ & $2.196 .042,66$ & $4.144 .197,43$ & $2.809 .941,15$ \\
\hline
\end{tabular}

Table 2. Statistical analysis of some of the major chemical constituents from groundwaters sampled in December 2004, June 2005 and November 2007 for each aquifer: a) $\csc (\mathrm{T})$; b) $\operatorname{cc}(\mathrm{G})$; c) $\operatorname{ccm}(\mathrm{C})$; d) $\operatorname{cpi}(\mathrm{OM})$; e) $\operatorname{cmc}(\mathrm{Mc})$.

a) $\csc (T)$ : limestone, dolomite and gypsum aquifer system

\begin{tabular}{|c|c|c|c|c|c|c|c|c|c|c|c|c|}
\hline & $\mathrm{T}$ & $\mathrm{pH}$ & $\mathrm{EC}$ & $\mathrm{Ca}^{2+}$ & $\mathrm{Mg}^{2+}$ & $\mathrm{Na}^{+}$ & $\mathrm{K}^{+}$ & $\mathrm{HCO}_{3}^{-}$ & $\mathrm{Cl}^{-}$ & $\mathrm{SO}_{4}^{2-}$ & $\mathrm{NO}_{3}^{-}$ & TDS \\
\hline \multicolumn{13}{|l|}{2004} \\
\hline Min & 15,6 & 6,3 & 1870 & 22,00 & 14,00 & 122,00 & 6,50 & 206,13 & 258,24 & 19,67 & 0,00 & 1275,93 \\
\hline Max & 21,9 & 8,9 & 7350 & 576,00 & 230,00 & 1440,00 & 63,00 & 582,74 & 2689,24 & 1813,18 & 548,60 & 5134,30 \\
\hline Ave & 18,8 & 7,0 & 3480 & 218,50 & 99,22 & 498,26 & 21,03 & 376,06 & 882,54 & 429,29 & 79,51 & 2629,80 \\
\hline SD & 1,88 & 0,62 & 1552,02 & 161,33 & 66,53 & 386,69 & 16,61 & 107,41 & 693,01 & 537,78 & 147,41 & 1137,33 \\
\hline \multicolumn{13}{|c|}{, } \\
\hline Min & 19,3 & 6,3 & 1890 & 9,00 & 27,70 & 94,00 & 9,75 & 215,40 & 220,46 & 0,00 & 0,00 & 1350,97 \\
\hline Max & 25,0 & 8,7 & 8260 & 325,00 & 231,00 & 1200,00 & 65,00 & 623,70 & 2692,26 & 874,00 & 291,38 & 5134,53 \\
\hline Ave & 22,7 & 7,1 & 3989 & 156,95 & 118,74 & 490,90 & 28,48 & 405,98 & 948,60 & 319,81 & 61,86 & 2549,16 \\
\hline SD & 1,75 & 0,75 & 2123,04 & 95,71 & 69,66 & 361,62 & 17,41 & 115,92 & 806,08 & 270,02 & 98,11 & 1203,27 \\
\hline \multicolumn{13}{|l|}{2007} \\
\hline Min & 16,7 & 0,8 & 1295 & 1,40 & 16,00 & 94,00 & 4,30 & 90,31 & 138,64 & 18,57 & 0,33 & 993,92 \\
\hline Max & 20,6 & 9,3 & 8690 & 520,00 & 240,00 & 1300,00 & 51,50 & 436,70 & 2901,72 & 1173,32 & 132,12 & 5292,71 \\
\hline Ave & 18,3 & 7,5 & 4077 & 191,30 & 96,75 & 522,64 & 20,66 & 314,37 & 1054,12 & 321,94 & 28,27 & 2570,87 \\
\hline SD & 1,10 & 0,83 & 2415,60 & 149,07 & 71,46 & 406,78 & 16,03 & 94,55 & 955,03 & 331,90 & 43,54 & 1424,71 \\
\hline
\end{tabular}

TDS, major cations and anions are in $\mathrm{mg} / \mathrm{l}$; temperature (T) is in ${ }^{\circ} \mathrm{C}$; electrical conductivity (EC) is at $25^{\circ} \mathrm{C}$ in $\mu \mathrm{S} / \mathrm{cm}$.

b) $c c(G)$ : limestone aquifer system

\begin{tabular}{|c|c|c|c|c|c|c|c|c|c|c|c|c|}
\hline & $\mathrm{T}$ & $\mathrm{pH}$ & $\mathrm{EC}$ & $\mathrm{Ca}^{2+}$ & $\mathrm{Mg}^{2+}$ & $\mathrm{Na}^{+}$ & $\mathrm{K}^{+}$ & $\mathrm{HCO}_{3}^{-}$ & $\mathrm{Cl}^{-}$ & $\mathrm{SO}_{4}^{2-}$ & $\mathrm{NO}_{3}^{-}$ & TDS \\
\hline \multicolumn{13}{|l|}{2004} \\
\hline Min & 15,2 & 6,4 & 802 & 58,00 & 12,00 & 42,00 & 2,25 & 185,80 & 85,46 & 10,51 & 0,00 & 656,33 \\
\hline Max & 21,6 & 7,6 & 2060 & 248,00 & 74,00 & 385,00 & 20,30 & 556,11 & 590,83 & 395,58 & 162,40 & 1588,69 \\
\hline Ave & 18,5 & 6,8 & 1296 & 140,89 & 33,61 & 123,34 & 6,02 & 400,33 & 219,76 & 94,50 & 39,42 & 1074,58 \\
\hline SD & 1,26 & 0,28 & 327,94 & 35,25 & 13,74 & 65,52 & 4,07 & 73,37 & 116,81 & 71,71 & 29,13 & 234,72 \\
\hline \multicolumn{13}{|l|}{2005} \\
\hline Min & 17,0 & 6,4 & 780 & 53,00 & 15,20 & 58,00 & 3,20 & 248,80 & 100,45 & 23,16 & 4,37 & 577,89 \\
\hline Max & 24,2 & 7,5 & 2280 & 275,00 & 68,20 & 370,00 & 20,75 & 570,80 & 586,34 & 392,94 & 136,25 & 1513,76 \\
\hline Ave & 21,0 & 6,8 & 1414 & 134,73 & 40,04 & 108,78 & 8,48 & 412,51 & 197,21 & 91,88 & 36,63 & 1044,98 \\
\hline $\begin{array}{l}\text { SD } \\
2007\end{array}$ & 1,84 & 0,27 & 384,86 & 46,03 & 13,70 & 65,66 & 5,12 & 92,21 & 111,55 & 82,99 & 30,92 & 253,80 \\
\hline Min & 15,9 & 6,8 & 811 & 54,50 & 14,10 & 53,00 & 2,00 & 240,00 & 84,74 & 20,77 & 0,62 & 576,79 \\
\hline Max & 20,1 & 7,7 & 3180 & 390,00 & 60,50 & 360,00 & 136,00 & 534,20 & 594,54 & 227,12 & 513,95 & 2173,28 \\
\hline Ave & 17,8 & 7,1 & 1469 & 146,94 & 32,50 & 106,65 & 15,15 & 410,70 & 212,55 & 71,90 & 50,20 & 1068,75 \\
\hline SD & 1,04 & 0,22 & 532,85 & 63,59 & 10,94 & 65,49 & 28,21 & 74,01 & 132,01 & 44,91 & 98,10 & 342,55 \\
\hline
\end{tabular}

TDS, major cations and anions are in $\mathrm{mg} / \mathrm{l}$; temperature (T) is in ${ }^{\circ} \mathrm{C}$; electrical conductivity (EC) is at $25^{\circ} \mathrm{C}$ in $\mu \mathrm{S} / \mathrm{cm}$. 
c) $\mathrm{ccm}(C)$ : limestone sequences aquifer system

\begin{tabular}{lrrrrrrrrrrrr}
\hline & $\mathrm{T}$ & $\mathrm{pH}$ & $\mathrm{EC}$ & $\mathrm{Ca}^{2+}$ & $\mathrm{Mg}^{2+}$ & $\mathrm{Na}^{+}$ & $\mathrm{K}^{+}$ & $\mathrm{HCO}_{3}^{-}$ & $\mathrm{Cl}^{-}$ & $\mathrm{SO}_{4}^{2-}$ & $\mathrm{NO}_{3}^{-}$ & $\mathrm{TDS}^{-}$ \\
\hline 2004 & & & & & & & & & & & & \\
Min & 17,5 & 6,5 & 673 & 46,00 & 12,50 & 69,00 & 2,70 & 168,93 & 106,47 & 38,42 & 0,00 & 500,20 \\
Max & 21,3 & 7,8 & 5140 & 305,00 & 135,00 & 860,00 & 69,00 & 658,68 & 1453,00 & 300,99 & 452,54 & 3513,80 \\
Ave & 19,3 & 7,0 & 2488 & 134,02 & 53,46 & 376,65 & 15,54 & 462,88 & 588,01 & 154,70 & 95,63 & 1922,09 \\
SD & 1,17 & 0,38 & 1103,18 & 65,80 & 32,73 & 230,06 & 14,96 & 106,94 & 369,17 & 76,81 & 116,09 & 728,93 \\
2005 & & & & & & & & & & & & \\
Min & 20,8 & 6,6 & 489 & 37,03 & 11,20 & 49,00 & 3,20 & 116,53 & 100,79 & 22,62 & 0,00 & 374,88 \\
Max & 24,4 & 7,6 & 5160 & 285,00 & 160,00 & 780,00 & 56,00 & 574,20 & 1258,02 & 315,20 & 235,75 & 3352,45 \\
Ave & 22,5 & 7,0 & 2424 & 140,90 & 65,89 & 268,90 & 18,03 & 426,27 & 481,99 & 153,91 & 71,20 & 1657,73 \\
SD & 1,19 & 0,37 & 1434,33 & 69,46 & 48,54 & 218,31 & 16,91 & 135,63 & 406,36 & 107,53 & 78,34 & 872,99 \\
2007 & & & & & & & & & & & & \\
Min & 13,0 & 6,7 & 422 & 28,50 & 7,45 & 38,00 & 4,80 & 91,30 & 72,52 & 15,94 & 0,62 & 266,73 \\
Max & 20,3 & 7,8 & 5450 & 262,00 & 129,50 & 880,00 & 45,00 & 594,60 & 1336,62 & 665,78 & 226,88 & 3605,76 \\
Ave & 17,7 & 7,0 & 2956 & 155,56 & 67,26 & 369,13 & 16,02 & 449,23 & 601,42 & 224,64 & 77,11 & 1997,40 \\
SD & 2,68 & 0,34 & 1536,68 & 67,91 & 42,82 & 265,64 & 13,89 & 174,81 & 435,44 & 196,76 & 94,30 & 982,14 \\
\hline
\end{tabular}

TDS, major cations and anions are in $\mathrm{mg} / \mathrm{l}$; temperature (T) is in ${ }^{\circ} \mathrm{C}$; electrical conductivity (EC) is at $25^{\circ} \mathrm{C}$ in $\mu \mathrm{S} / \mathrm{cm}$.

d) cpi (OM): pyroclastic aquifer system

\begin{tabular}{lrrrrrrrrrrrr}
\hline & $\mathrm{T}$ & $\mathrm{pH}$ & $\mathrm{EC}$ & $\mathrm{Ca}^{2+}$ & $\mathrm{Mg}^{2+}$ & $\mathrm{Na}^{+}$ & $\mathrm{K}^{+}$ & $\mathrm{HCO}_{3}^{-}$ & $\mathrm{Cl}^{-}$ & $\mathrm{SO}_{4}^{2-}$ & $\mathrm{NO}_{3}^{-}$ & $\mathrm{TDS}^{-}$ \\
\hline 2004 & & & & & & & & & & & \\
Min & 13,4 & 5,7 & 332 & 9,00 & 7,00 & 43,50 & 1,60 & 17,94 & 61,27 & 14,97 & 0,00 & 226,63 \\
Max & 22,4 & 7,6 & 4420 & 428,00 & 140,00 & 630,00 & 24,00 & 522,79 & 1273,88 & 1248,18 & 133,28 & 2884,21 \\
Ave & 17,6 & 6,6 & 1683 & 67,05 & 43,09 & 220,00 & 10,79 & 146,18 & 416,71 & 100,75 & 23,51 & 1096,48 \\
SD & 1,97 & 0,47 & 1076,24 & 77,18 & 35,51 & 152,86 & 5,82 & 115,81 & 340,48 & 220,63 & 30,89 & 717,93 \\
2005 & & & & & & & & & & & & \\
Min & 19,5 & 6,0 & 797 & 19,25 & 7,65 & 92,00 & 7,25 & 22,00 & 200,65 & 31,83 & 0,00 & 531,57 \\
Max & 24,7 & 7,0 & 4630 & 164,00 & 176,00 & 570,00 & 33,00 & 469,00 & 1427,72 & 239,25 & 152,37 & 2948,87 \\
Ave & 22,1 & 6,5 & 2370 & 76,93 & 66,07 & 295,70 & 19,06 & 179,75 & 647,35 & 92,45 & 39,97 & 1482,80 \\
SD & 1,82 & 0,38 & 1472,87 & 49,93 & 53,49 & 184,89 & 9,15 & 120,12 & 480,13 & 65,34 & 58,24 & 855,59 \\
2007 & & & & & & & & & & & \\
Min & 16,2 & 6,1 & 863 & 23,00 & 10,10 & 108,00 & 7,30 & 22,50 & 207,72 & 33,39 & 0,21 & 551,83 \\
Max & 20,6 & 7,3 & 4730 & 156,00 & 124,00 & 800,00 & 23,00 & 333,60 & 1479,82 & 179,69 & 160,73 & 2937,91 \\
Ave & 18,6 & 6,7 & 2461 & 76,94 & 55,19 & 353,11 & 12,77 & 156,28 & 658,25 & 86,97 & 41,84 & 1508,82 \\
SD & 1,36 & 0,40 & 1557,11 & 46,47 & 36,37 & 238,27 & 4,96 & 91,96 & 484,90 & 55,67 & 55,97 & 865,89 \\
\hline
\end{tabular}

TDS, major cations and anions are in $\mathrm{mg} / \mathrm{l}$; temperature (T) is in ${ }^{\circ} \mathrm{C}$; electrical conductivity (EC) is at $25^{\circ} \mathrm{C}$ in $\mu \mathrm{S} / \mathrm{cm}$.

e) $c m c(M c)$ : sandstone and limestone aquifer system

\begin{tabular}{lrrrrrrrrrrrr}
\hline \multicolumn{1}{c}{$\mathrm{T}$} & $\mathrm{pH}$ & \multicolumn{1}{c}{$\mathrm{EC}$} & $\mathrm{Ca}^{2+}$ & $\mathrm{Mg}^{2+}$ & $\mathrm{Na}^{+}$ & $\mathrm{K}^{+}$ & $\mathrm{HCO}_{3}^{-}$ & $\mathrm{Cl}^{-}$ & $\mathrm{SO}_{4}^{2-}$ & $\mathrm{NO}_{3}^{-}$ & $\mathrm{TDS}^{-}$ \\
\hline 2004 & & & & & & & & & & & & \\
Min & 15,0 & 6,4 & 646 & 94,00 & 7,00 & 25,50 & 1,70 & 270,37 & 55,72 & 16,90 & 7,45 & 516,46 \\
Max & 18,0 & 6,9 & 938 & 131,00 & 19,00 & 57,00 & 3,20 & 385,69 & 110,11 & 54,91 & 43,05 & 775,65 \\
Ave & 16,2 & 6,7 & 783 & 113,50 & 12,00 & 38,75 & 2,58 & 319,70 & 75,20 & 34,19 & 26,68 & 641,85 \\
SD & 1,30 & 0,24 & 139,76 & 16,34 & 5,43 & 13,63 & 0,63 & 54,22 & 24,45 & 19,04 & 16,98 & 126,76 \\
2005 & & & & & & & & & & & & \\
Min & n.d. & n.d. & n.d. & n.d. & n.d. & n.d. & n.d. & n.d. & n.d. & n.d. & n.d. & n.d. \\
Max & n.d. & n.d. & n.d. & n.d. & n.d. & n.d. & n.d. & n.d. & n.d. & n.d. & n.d. & n.d. \\
Ave & n.d. & n.d. & n.d. & n.d. & n.d. & n.d. & n.d. & n.d. & n.d. & n.d. & n.d. & n.d. \\
SD & n.d. & n.d. & n.d. & n.d. & n.d. & n.d. & n.d. & n.d. & n.d. & n.d. & n.d. & n.d. \\
2007 & & & & & & & & & & & & \\
Min & 17,4 & 6,8 & 834 & 90,00 & 7,00 & 31,00 & 2,10 & 309,40 & 70,57 & 18,30 & 3,99 & 645,22 \\
Max & 20,3 & 7,3 & 3610 & 380,00 & 78,50 & 225,00 & 16,10 & 425,90 & 546,85 & 201,54 & 654,62 & 2473,80 \\
Ave & 18,8 & 7,1 & 1598 & 175,43 & 30,48 & 111,71 & 5,97 & 358,00 & 243,81 & 58,69 & 139,48 & 1142,25 \\
SD & 1,07 & 0,15 & 963,22 & 98,82 & 25,46 & 75,99 & 5,04 & 42,31 & 176,94 & 65,58 & 229,04 & 631,86 \\
\hline
\end{tabular}

TDS, major cations and anions are in $\mathrm{mg} / \mathrm{l}$; temperature (T) is in ${ }^{\circ} \mathrm{C}$; electrical conductivity (EC) is at $25{ }^{\circ} \mathrm{C}$ in $\mu \mathrm{S} / \mathrm{cm} ; \mathrm{n} . \mathrm{d}$. $=$ not detected. 
TDS and chloride concentrations which, along with other hydrogeochemical evidence, rules out sea water intrusion as the cause of high salinity. The high chloride and sulphate concentrations can be related to deep hydrothermal circuits and to Triassic evaporites, respectively. The source water chemistry has been modified by various geochemical processes due to the groundwaterrock interaction, including ion exchange with hydrothermal minerals and clays, incongruent solution of dolomite, and sulphate reduction (Ghiglieri et al., 2009a);

- to identify and to survey the actual or potential pollution sources (Barbieri et al., 2005; Ghiglieri et al., 2006, 2008, 2009b);

- to evaluate the potential risk of nitrate pollution in the aquifers from agricultural practices (Ghiglieri et al., 2009b) by combining intrinsic aquifer vulnerability to contamination, according to SINTACS R5 method (Civita and De Maio, 2000; Civita et al., 2007), and agricultural nitrates hazard assessment, according to IPNOA index (Padovani and Trevisan, 2002). Figure 2 shows the areal frequency distribution of the SINTACS vulnerability degree in the study area: the vulnerability classes $(\mathrm{M})$ and $(\mathrm{H})$, corresponding to medium and high level, are distributed on $38 \%$ of the total area; the most of the land area is characterized by low and very low level, accounting for $43 \%$ and $18 \%$ of the total respectively (Ghiglieri et al., 2008). Regarding the agricultural nitrates hazard index (IPNOA) (Ghiglieri et al., $2009 \mathrm{~b}$ ), the most represented classes are improbable $(8.7 \%)$ and very low $(59.9 \%)$; low $(3.1 \%)$ and moderate $(0.05 \%)$ (Fig. 3). Five potential risk levels have been identified within the catchment area: their areal frequency distribution is shown in Figure 4. As can be seen, low and moderate classes are similarly distributed, accounting for $25 \%$ and $21 \%$ of the total land area respectively. Very high and high classes occur above all in the central part of the plain, but affect much smaller percentages of land area. Interestingly, intrinsic vulnerability in this part of the catchment basin is high and most of the potential pollution sources are concentrated therein (Ghiglieri et al., 2009b).

The potential risk areas can be associated with input-intensive farming (irrigation, fertilization and use of agrichemicals), mainly vineyards, market garden and protected crops. Fur-
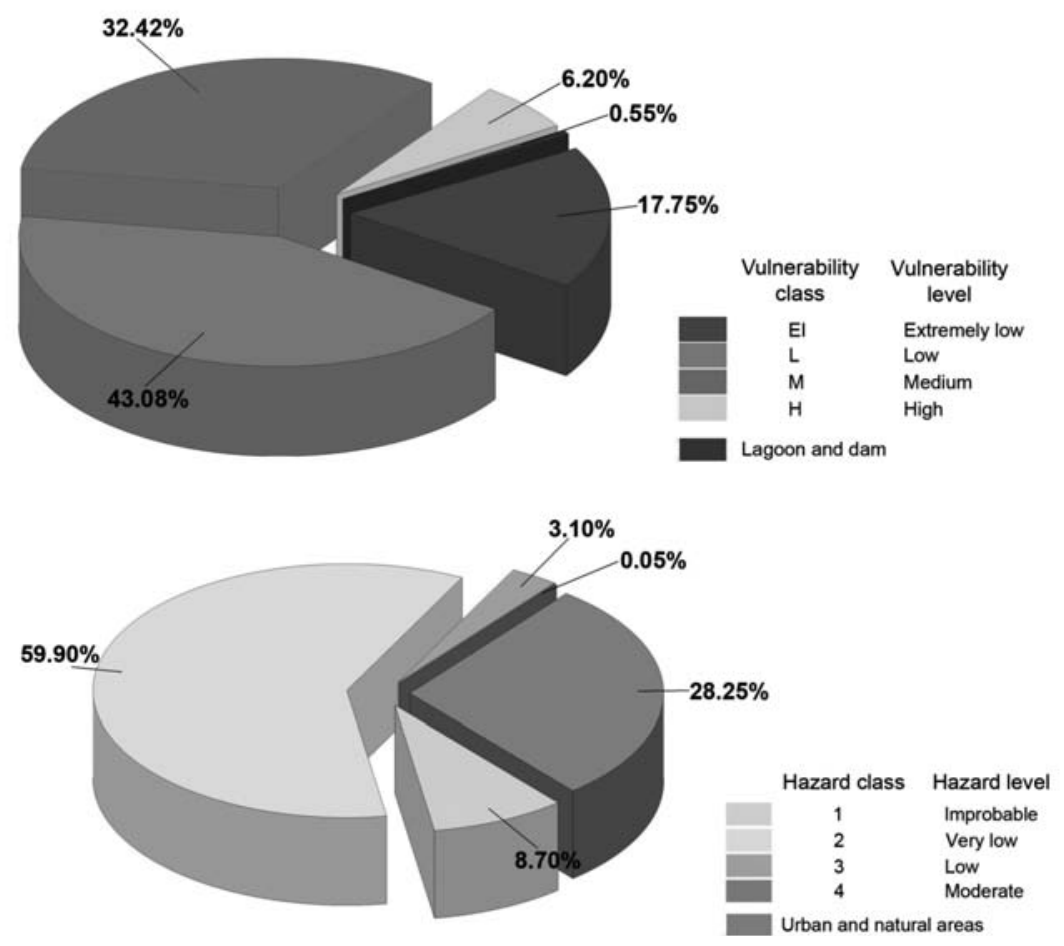

Figure 2. Areal frequency SINTACS vulnerability degree distribution (modified from Ghiglieri et al., 2006, 2008).
Figure 3. Areal frequency Agricultural Nitrates Hazard (IPNOA) distribution (modified from Ghiglieri et al., 2006). 


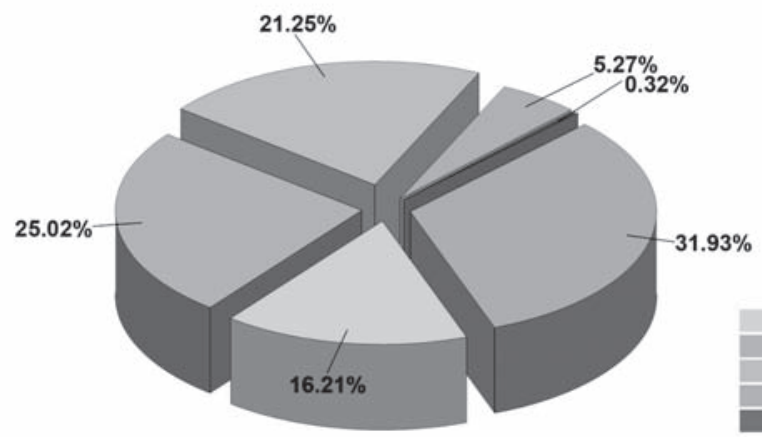

$\begin{array}{ll}\begin{array}{c}\text { Potential risk } \\ \text { class }\end{array} & \begin{array}{c}\text { Potential risk } \\ \text { level }\end{array} \\ 1 & \text { Very low } \\ 2 & \text { Low } \\ 3 & \text { Moderate } \\ 4 & \text { High } \\ 5 & \text { Very high } \\ \text { Urban and natural areas }\end{array}$

Figure 4. Areal frequency distribution: Potential Risk of nitrate pollution in aquifer from agricultural practices (modified from Ghiglieri et al., 2006). thermore, the area is characterized by a major industrial agglomeration, two urban centres (dense residential fabric) and scattered urbanization (dispersed residential fabric) (Ghiglieri et al., 2009b).

Achieving these aims will establish a basis for developing an appropriate monitoring programme and therefore improved management of the water resources of the region (Ghiglieri et al., 2006, 2007, 2008).

The multidisciplinary approach, developed in the RIADE Project, certainly provides authorities with a planning tool for water resources and soil protection, for identifying desertification and land degradation processes and for formulating suitable policies for attenuating anthropogenic impact.

Moreover, the experimental data and the conceptual models developed so far will constitute the basis for the implementation of a dynamic simulation model and a decision support system for integrated environmental management.

The study also aimed to gain a better understanding of desertification processes, in terms of degradation of water and natural resources and consequently to mitigate its effects. The approach used here was aimed at developing a methodological tool which can be applied to different scenarios.

\section{Acknowledgment}

The financial support from Italian Ministry of Education, University and Research (MIUR) for the development of the research RIADE (Integrated Research for Applying new technologies and processes for combating Desertification, www.riade.net) is acknowledged. Thanks are due also to Fondazione Banco di Sardegna for the financial support to Mr. D. Pittalis.

\section{References}

Barbieri G., Ghiglieri G., Vernier A. 2005. Design of a groundwater monitoring network and identification of environmental quality indicators for combatting desertification. $2^{\text {nd }}$ International Workshop - AVR 05 Aquifer Vulnerability and Risk $054^{\circ}$. Convegno nazionale sulla protezione e gestione delle acque sotterranee, Parma 2005 - Atti (ID259), ISBN 88-9013422-4, GEAM. Rivista IGEA - Ingegneria e Geologia degli Acquiferi [Groundwater Geoengineering] 2006 ISSN 1121-9041, 21:71-80.

Civita M., De Maio M. 2000. SINTACS R5 a new parametric system for the assessment and automatic mapping of groundwater vulnerability to contamination Quaderni di Tecniche di Protezione Ambientale, 72, Pitagora Editrice, Bologna, ISBN 88-371-1231-9, 226 pp.

Civita M., Fiorucci A., Vigna B. 2007. The Spatial-Temporal Variability of Nitrates in a Section of the $\mathrm{Cu}$ neo Plain (North West Italy). American Journal of Environmental Sciences 3 (3), 111-116, ISSN 1553$345 X$.

De Maio M., Fiorucci A., Offi M. 2007. Risk of groundwater contamination from nitrates in the Po basin (Italy). Water Science \& Technology: Water Supply Vol. 7, N. 3, 83-92, (C) IWA Publishing 2007, doi 10.2166/ws.2007.070.

Dono G., Marongiu S., Severino S., Sistu G., Strazzera E. 2008. Studio sulla gestione sostenibile delle risorse idriche: analisi dei modelli di consumo per usi irrigui e civili [Sustainable water resources management: criteria water consuption models for irrigation and civil use], ISBN 88-8286-155-4, 257 pp.

Ghiglieri G., Barbieri G., Vernier A. 2006. Studio sulla gestione sostenibile delle risorse idriche: dall'analisi conoscitiva alle strategie di salvaguardia e tutela [Sustainable water resources management: knowledge and protection criteria], ISBN 88-8286-147-3, 550 pp.

Ghiglieri G., Barbieri G., Vernier A., Carletti A., Demurtas N., Deroma M., Pinna R., Pittalis D., Vigo A. 2007. Carta idrogeologica e rete di monitoraggio corpi idrici superficiali e sotterranei Nurra (Sardegna Nord-Occidentale). Scala 1:50.000. ISBN 88-8286 
Stampa Composita [Hydrogeological Map of the Nurra area (NW Sardinia): surface water and groundwater monitoring network. Scale 1:50.000. Edit by Composita].

Ghiglieri G., Barbieri G., Vernier A., Carletti A., Dore M., Demurtas N., Pinna R., Pittalis D., Vargiu M. 2008. Vulnerabilità all'inquinamento degli acquiferi della Nurra di Alghero (SS) per la gestione integrata delle risorse idriche (Sardegna NW) [Aquifer vulnerability in the Nurra Region (Alghero) for integrated water resources management: NW Sardinia]. Rivista IGEA - Ingegneria e Geologia degli Acquiferi [Groundwater Geoengineering], ISSN 1121-9041, 23:77-86.

Ghiglieri G., Oggiano G., Fidelibus D., Barbieri G., Vernier A., Tamiru A., 2009a. Hydrogeology of the Nurra Region, Sardinia (Italy): basement - cover influences on groundwater occurrence and hydrogeochemistry. Hydrogelogy Journal Springer Verlag, ISSN 1431-2174, Vol. 17, Issue 2, 447-466.
Ghiglieri G., Barbieri G., Vernier A., Carletti A., Demurtas N., Pinna R., Pittalis D. 2009b. Potential risks of nitrate pollution in aquifers from agricultural practices in the Nurra region, northwestern Sardinia, Italy. Journal of Hydrology, ISSN 0022-1694, Vol. 379, Issues 3-4, 339-350.

Padovani L., Trevisan M. 2002. I nitrati di origine agricola nelle acque sotterranee [Nitrates of agricultural origin in groundwater]. Quaderni di Tecniche di Protezione Ambientale, Pitagora Editrice, Bologna, ISBN 88-371-1260-2, 75: 103 pp.

RIADE Project 2003-2006. Integrated Research for Applying new technologies and processes for combating Desertification, http://www.riade.net.

UNEP 1994. United Nations Convention to Combact Desertification in those countries experiencing serious drought anf/or desertification, particularly in Africa. UNEP, Genève. 